\title{
Assessment of Agrocenosis Adaptability of Winter Wheat in the Conditions of the Foothill Zone of the Central Caucasus
}

\section{Irina Manukyan, Elena Miroshnikova, Madina Basieva, and Nino Doguzova}

North Caucasian Research Institute of Mountain and Piedmont Agriculture - Affiliate of Vladikavkaz Scientific Center of the Russian Academy of Sciences, Mikhailovskoye, Russia

ORCID:

Elena Miroshnikova: http://orcid.org/0000-0003-0208-3631

\section{Abstract}

This paper presents the results of multi-year research on the adaptability of winter wheat varieties to the conditions of the foothill zone of the Central Caucasus. Characteristics such as ductility and stability were used to assess varieties for conformity to the cultivation conditions. Plant homeostaticity served as the indicator of ontogenetic adaptability. Phenological observations and reports were carried out according to the

Corresponding Author:

Elena Miroshnikova

mirlen@mail.ru

Published: 5 April 2021

Publishing services provided by Knowledge E

(c) Irina Manukyan et al. This article is distributed under the terms of the Creative Commons Attribution License, which permits unrestricted use and redistribution provided that the original author and source are credited.

Selection and Peer-review under the responsibility of the DonAgro Conference Committee. state variety testing methodology. The species composition of weed vegetation was established using the Agroecological Atlas of Russia. Conventional insect accounting methods were used to consider phytophages and plants damaged by them. It was established that the dominant pests of winter grains in the early periods of vegetation include phytophage bugs and cereal leaf beetle Oulema melanopus $L$. The maximum number of phytophage bugs was noted during the earing-flowering period. The proportion of pathogens of spike Fusarium head blight, tan spot and Septoria spot prevailed in the pathogenic complex. In total, $36.7 \%$ of varieties, including Kuma, Deya, Esaul, Starshina, Delta, Nota and Antonina, were medium-resistant to Fusarium head blight damage. According to the results of a comprehensive assessment of winter wheat selection by the parameters of adaptability, productivity and resistance to diseases, highly plastic genotypes responsive to environmental factors were distinguished: Kuma, Deya, Veda, Tanya, and List 25 (bi = 2.2; 2,3; 2,1). The selection of varieties was based on the adaptive properties of winter wheat. Fusarium head blight decreased by $20.8 \%$ in the mixed variety Batko+Deya, and the yield of mixed variety crops increased by $9 \%$. Methods for compiling mixed varieties and designing the mosaics of varieties in the area of grain agrocenosis are recommended.

Keywords: winter wheat, sustainability of agrocenosis, productivity, ecological plasticity, mixed varieties.

\section{Introduction}


by human economic activity - agrocenoses [1]. Agrocenoses differ from natural ecosystems by thier high productivity, low diversity of living organisms, low ecological stability, because cultivated varieties are extremely sensitive to pests and diseases, do not withstand competition with wild species [2]. Without human support, agrocenoses are not capable of self-regulation and self-renewal, are threatened by the mass reproduction of pests or pathogens [3].

The structure of the grain area within the structure of crop rotation plays an important role in the rational use of natural resources. It is possible to increase the stability and productivity of grain agrocenosis by structuring it based on the selection of adapted winter wheat varieties and their placement on the crop rotation area $[4,5]$.

The purpose of the study is to increase the environmental sustainability of grain agrocenosis as the main reserve for environmental safety and increased productivity of winter wheat.

In order to fulfill this purpose, the peculiarities of soil-climatic and biotic factors of the region were studied, integrated assessment of winter wheat varieties for resistance to the main types of diseases and pests, adaptability to cultivation conditions was carried out. The methods of constructing grain agrocenosis following the principle of mosaic of varieties and mixed varieties that increase biological (genetic) diversity of crop rotation are recommended.

\section{Methods and Equipment}

\subsection{Methods}

The studies were carried out in 2017-2019 in the Laboratory of Grain Crops Selection and Seed Production of the North Caucasian Research Institute of Mountain and Piedmont Agriculture of the Russian Academy of Sciences. The material for the research included 50 varieties of winter soft wheat Triticum aestivum $L$. from the world collection of the N.I. Vavilov Institute of Plant Genetic Resources.

The foothill zone of the Central Caucasus is characterized by excessive moistening during the earing and grain growth period (May-June) and the arid autumn period (September-November). Soils belong to leached pre-Caucasian chernozems. The changes in climatic conditions for the foothill zone of the Central Caucasus are mostly reflected in the winter period. The average winter temperature has increased and ranges from +1 to +3 , the amount of rainfall has decreased to $16.9-23.8 \mathrm{~mm}$. Undoubtedly, 
climatic changes affect the activity and vital functions of weed vegetation, disease excitants and insects of phytophages.

Phenological observations and reports were carried out according to the state variety testing methodology. The species composition of weed vegetation was established using the Agroecological Atlas of Russia [6]. The conventional insect accounting methods were used to consider phytophages and plants damaged by them [7].

To assess the adaptive properties, stability and ecological plasticity (bi) we used the method of S.A. Eberhart, W.A. Russell in the presentation of V.Z. Pakudin and L.M. Lopatina [8], stress resistance (Ymin - Ymax) and genetic flexibility ((Ymax + Ymin) / 2) were determined according to A.A. Rossielle, J. Hemblin [9]. The variation coefficient was calculated according to B.A. Dospekhov [10]. Homeostaticity (Hom) was calculated by V.V. Khangildin and N.A. Litvinenko [11].

\section{Results}

Species biodiversity represents a unique feature of wildlife. Natural biocenoses are characterized by stability over time and resistance to changing environmental factors. In contrast, human-made agrosystems have high productivity, but low resistance to biotic and abiotic, stressful environmental factors, are characterized by a limited species composition of phytocenosis, genetic homogeneity of varieties.

In this regard, a "flexible" species and variety structure of winter crop acreage has become widespread in the system of adaptive crop production, which is formed taking into account the ecological plasticity of varieties, resistance to diseases, as well as the phytosanitary situation in the region [12]. Modern variety policy developed by the leading scientists of the National Center of Grain named after P.P. Lukyanenko offers the cultivation of a wide range of varieties that are characterized by a number of biological and economic-valuable features, their targeted use following the principle of "mosaic" placement, limiting share of the variety in the total area of crops to not more than $15 \%$ depending on adaptive properties. The main provisions of the variety policy are timely variety changing and mosaic placement of varieties in crop rotation fields, their alternation in time and space.

In the conditions of the foothill zone of the Central Caucasus, the moisture availability of winter wheat crops during the growing season varies significantly. The autumn period is characterized by an arid period from September to November, almost every year there is an autumn drought. The winter period is quite warm with little snow. From the beginning of March-April, the reserves of productive moisture in the soil in dry years 
can be 11-18 mm, which is not enough for plants, especially during the initiation of ear. In May-June, the amount of rainfall, as a rule, exceeds the norm by $135-150 \%$. Short crop rotation prevails in the region, $70 \%$ of arable land is occupied by grain maize. Maize is not the best precursor for winter wheat, because it has a long growing season, consumes a significant amount of nutrients and accumulates fusarial infection.

The species composition of phytophages on winter wheat is represented by more than 50 species of insect orders: lepidopterans or butterflies (Lepidoptera), coleopterans or beetles (Coleoptera), dipterans (Diptera), hemipterans or bugs (Hemiptera), thysanopterans (Thysanoptera), homopterans (Homoptera), etc.

The observations of the species composition of pests on winter wheat made it possible to distinguish the most significant types of phytophages and periods of their harmfulness. The main changes concern the number and harmfulness of sucking pests: bugs, frog-flies, thunder flies and aphids. For example, it was noted that the number of aphids on the crops of winter wheat and triticale was reduced to single small colonies due to the increase in the number of their natural enemies - ladybugs - afidophages (Coccinellidae) and predatory bugs (Nabidae, Anthocoridae).

The dominant pests of winter grains in the early periods of vegetation are the following: phytophage bugs and cereal leaf beetle Oulema melanopus $L$. The maximum number of phytophage bugs was noted during the earing-flowering period.

From the period of spring vegetation to milky ripeness, the main damage to the leaves by skeletization type is caused by cereal leaf beetle Oulema melanopus L. (Coleoptera, Chrysomelidae).

The species composition of phytophage bugs on winter grain crops is represented by 5 families. Two families are dominant in number: Miridae - capsid bugs (Trigonotylus ruficornis G., Lygus rugulipennis $P_{\text {.) }}$ ) and Pentatomidae - stinkbugs (Eurigaster intergriceps, Dolycoris baccarum L., Aelia acuminata).

The stinkbug family (Heteroptera, Pentatomoidea) is represented by 8 species, 5 of which belong to the family of real stinkbugs (Pentatomidae) - this is Aelia acuminata L., Dolycoris baccarum L., Eysarcoris ventralis $W$. and singly spring stinkbug (Holcostethus vernal) and gray stinkbug (Elasmucha grisea L.), as well as 3 species of shield-backed bugs (Scutelleridae) - this is Eurygaster integriceps Put., E. maura L. and E. austriacus Schr.

Over the years, more than 30 species of phytopathogens have been recorded on winter wheat, including 31 species of fungi, 6 species of bacteria and 1 species of virus. The malicious complex of diseases is represented by various pathogens, among which the most common are the pathogens of Fusarium head blight - Fusarium graminearum 
Schw., brown rust - Puccinia triticina R., yellow rust - Puccinia striiformis West., tan spot or leaf spackled yellows - Pyrenophora tritici-repentis Died., speckled leaf blotch - Septoria tritici $R$. In the pathogenic complex, the proportion of pathogens of Fusarium head blight, tan spot and Septoria spot prevails. The distribution of powdery mildew is decreasing. The varieties are quite different in terms of their resistance to diseases, in particular to Fusarium head blight. Most varieties (40\%) are medium-susceptible to Fusarium head blight, while $23.3 \%$ are susceptible. The medium-resistant type included 36.7\% varieties: Kuma, Deya, Esaul, Starshina, Delta, Nota, Antonina, etc. (Table 1).

TABLE 1: Immunological characteristics of winter wheat varieties by the degree of resistance to Fusarium head blight.

Medium-resistant
Starshina, Tanya, Deya,
Zimorodok, Nota, Kuma, Esaul,
Delta, Moskvich, Don 107,
Antonina

Medium-susceptible

Leda, Pamyat, Grom, Fortuna,

Vostorg, Batko, Fisht, Veda,

Etnos, Alekseich, Esaul, Kroshka

Antonina

\section{Susceptible}

Utrish, Zira, Lira, Pobeda 50, List 25, Bezostaya 100, Irishka

The obtained data make it possible to differentiate the varieties for sowing by maize grain precursor, since this crop is a cradle for fusarial infection. This crop is one of the main precursors for winter wheat in the republic, so it is important to know the resistance of varieties to Fusarium head blight, to choose varieties that are resistant and medium-resistant to this disease for maize sowing.

It is believed that the heterogeneity of the cultivated land particularly effectively prevents the transfer of Fusarium head blight inoculum and other diseases, reduces harmful prevalence of crops. The equipped cultivated land implies the mosaic structure or diversity of winter wheat varieties that differ in maturity group (from ultra-early ripening to middle-late), as well as the targeting of varieties, i.e. their maximum adaptation to environmental, soil features of the economy, the structure of predecessors, economic and technical capabilities of land users. Agroecosystems with more diverse variety composition make more use of environmental resources. We studied several variants of mixed varieties in which 2-4 varieties of winter wheat can be used, which are distinguished by their genetic nature and resistance to phytopathogens. An important condition is that the varieties should be close in ripening time and height. For example, the Batko+Deya mixed variety takes into account the fact that the Deya variety has greater resistance to a complex of diseases, including Fusarium head blight. In mixed variety crops, the intensity of disease development, including Fusarium head blight, decreased by $20.8 \%$, and the number of fusarial grains amounted to $7.8 \%$, while in Batko crops, the development of Fusarium head blight was $45.7 \%$, and the number of 
fusarial grains amounted to $18.2 \%$. The yield of mixed variety crops was $4.5 \mathrm{t} / \mathrm{ha}$, the gain made $9 \%$.

In triple mixed crops of strong varieties of Veda and Delta (25\% each) with a valuable variety Batko (50\%) characterized by the degree of resistance to various diseases the average yield made $52 \mathrm{c} /$ ha with protein content $-12 \%$, gluten $-28 \%$, flour strength 320.

In addition to the above-mentioned technological methods for compiling mixed varieties, the ecologically sound cultivated lands is an agricultural factor that reduces the harmful nature of diseases and increases the yield and quality of grain. The type of placement of varieties is most effective in planning protective measures against pests and diseases. We used the resistance of the early-mature Kuma variety to cereal leaf beetle damage as protective, screen seeding around the perimeter of the field. Such sowing of a stable variety prevents pests from inhabiting other crops of less stable varieties.

The calculation of adaptability parameters based on the yield over the last three years is shown in Example 8 of the samples (Table 2). The variance analysis showed that the contribution of productivity to the overall variability belongs to the genotypes of the studied varieties (the "variety" factor), their share was $50 \%$. The share of variability caused by the influence of environmental conditions (the "year" factor) was $26.5 \%$. The share of other factors was $23.5 \%$.

The degree of genotype response to environmental changes or ecological plasticity is well described by the regression coefficient $\left(b_{i}\right)$, which shows the plasticity of the variety, indicates its ability to sustain productivity when growing conditions deteriorate. Stable varieties ensure the reliability of grain production especially in unfavorable years. Especially valuable are those varieties in which $b_{i} \geq 1$, they can increase the productivity while improving the growing conditions. Homeostaticity reflects the ability of the variety to support synthesis and accumulation of plastic substances under various growing conditions, the higher this indicator, the more stable the variety in various years (Table 3).

The varieties Don 107 and Pamyat showed low indicators of ecological plasticity $\left(b_{i}<1\right)$ -0.9 and 0.8 . They have an average adaptation to adverse conditions, but are able to provide a stable crop in various conditions and in "poor" soil fertility. The conditions of the year had a significant impact on the productivity of the varieties Tanya, Veda, Deya, List 25, Kuma ( $\mathrm{b}_{i}$ varied from 2.1 to 2.3 ) (Table 3).

The Tanya variety, in which $\mathrm{b}_{i}$ exceeded 1 (2.2), also had high homeostasis score (Hom=577). This variety is effectively cultivated using intensive technology. Kuma and 
TABLE 2: Results of the variance analysis by the yield of varieties.

\begin{tabular}{|c|c|c|c|c|c|c|}
\hline \multirow[t]{2}{*}{ Variance type } & \multirow{2}{*}{$\begin{array}{c}\text { Sum of } \\
\text { squared } \\
\text { deviations }\end{array}$} & \multirow{2}{*}{$\begin{array}{l}\text { Number of } \\
\text { degrees of } \\
\text { freedom }\end{array}$} & \multirow{2}{*}{$\begin{array}{l}\text { Average } \\
\text { square }\end{array}$} & \multirow{2}{*}{$\begin{array}{c}\text { Share of } \\
\text { factor con- } \\
\text { tribution, } \\
\%\end{array}$} & \multicolumn{2}{|c|}{ Variance ratio (F) } \\
\hline & & & & & actual & tabular \\
\hline Total & 0.68 & 32 & 0.021 & - & & \\
\hline $\begin{array}{l}\text { "Year" factor } \\
\text { A }\end{array}$ & 0.18 & 2 & 0.9 & 26.5 & 112.5 & 5.9 \\
\hline $\begin{array}{l}\text { "Variety" } \\
\text { factor B }\end{array}$ & 0.34 & 10 & 0.034 & 50.0 & 42.5 & 2.4 \\
\hline Residual & 0.16 & 20 & 0.008 & 23.5 & & \\
\hline
\end{tabular}

TABLE 3: Adaptability parameters of winter wheat varieties in conditions of the foothill zone of the Central Caucasus.

\begin{tabular}{l|c|c|}
\hline Variety & $\begin{array}{c}Y \min -\mathrm{Y} \\
\mathrm{max}, \mathrm{t} / \mathrm{ha}\end{array}$ & $\begin{array}{c}(\mathrm{Y} \max +\mathrm{Y} \\
\mathrm{min}) / 2, \mathrm{t} / \mathrm{ha}\end{array}$ \\
\hline Don 107 & -0.58 & 3.74 \\
\hline Tanya & -0.57 & 4.16 \\
\hline Pamyat & -0.13 & 4.00 \\
\hline List 25 & -0.24 & 4.01 \\
\hline Kuma & -0.58 & 4.46 \\
\hline Veda & -0.69 & 4.26 \\
\hline Deya & -0.6 & 4.64 \\
\hline Batko & -0.48 & 4.59 \\
\hline
\end{tabular}

\begin{tabular}{|c|}
$\begin{array}{c}\text { Average } \\
\text { t/ha }\end{array}$ \\
\hline 3.66 \\
\hline 4.23 \\
\hline 4.01 \\
\hline 4.43 \\
\hline 4.43 \\
\hline 4.13 \\
\hline 4.56 \\
\hline 4.60 \\
\hline
\end{tabular}

\begin{tabular}{|l|}
\hline $\mathrm{b}_{i}$ \\
\hline 0.9 \\
2.1 \\
0.8 \\
2.2 \\
\hline 2.2 \\
\hline 2.3 \\
\hline 2.2 \\
\hline 1.6
\end{tabular}

\begin{tabular}{|l|}
\hline Hom \\
\hline 339 \\
577 \\
570 \\
378 \\
467 \\
\hline 437 \\
\hline 375 \\
\hline 384
\end{tabular}

Veda varieties have similar $b_{i}$ and Hom values and respond positively to improved growing conditions and high soil fertility.

Deya and Batko varieties had high yields -4.56 and $4.60 \mathrm{t} / \mathrm{h}$ a and similar homeostatic indicators -378 and 384 . The ecological plasticity $\left(b_{i}\right)$ of the Batko variety was $b_{i}=1.6$, which indicates more stable productivity and responsiveness to improved cultivation conditions.

\section{Discussion}

The assortment of winter wheat varieties, which showed the features of adaptability to cultivation conditions in the foothill zone of the Central Caucasus, is the biological (genetic) material that is necessary for the design of adaptive agroecosystems. It was established that the heterogeneity of the cultivated land especially effectively prevented the transfer of Fusarium head blight and other diseases, reduced the prevalence of crops with harmful diseases. The efficient cultivated land implies mosaic structure or diversity of winter wheat varieties that differ in the maturity group (from ultra-early ripening 
to middle-late), as well as the targeting of varieties, i.e. their maximum adaptation to environmental, soil features of the economy, the structure of predecessors, economic and technical capabilities of land users. Agroecosystems with more diverse variety composition make more use of environmental resources [12, 13].

\section{Conclusion}

According to the results of a comprehensive assessment of the selection material of winter wheat according to the parameters of adaptability, productivity and resistance to diseases, highly plastic genotypes, responsive to improving environmental factors were distinguished: Kuma, Deya, Veda, Tanya, List $25\left(b_{i}=2.2 ; 2.3 ; 2.1\right)$. It is possible to increase the genetic diversity of agroecosystems by increasing the number of cultivated species in crop rotation, as well as the genetic diversity of varieties using varietal mosaics and mixed varieties. Thus, the mixed varieties Batko+Deya are characterized by the intensity of disease development, including Fusarium head blight, which decreased by $20.8 \%$, and the yield of mixed varieties crops increased by $9 \%$.

Thus, it is possible to increase the stability and productivity of grain agrocenosis by taking into account biological and genetic diversity of varieties, their targeted and spatial placement. The genetic diversity of varieties creates conditions for regulating and stabilizing the phytosanitary state of crops and increasing productivity. Due to this agricultural technique, it becomes possible to regulate and stabilize the phytosanitary situation in the fields, improve the productivity and quality of grain.

\section{Acknowledgement}

The authors would like to express gratitude to their colleagues for their contribution and support in this study. They are also grateful to all reviewers who made valuable contributions to the work on the manuscript and helped in its completion.

\section{Conflict of Interest}

The authors have no conflict of interest to declare. 


\section{References}

[1] Naumkin, V. N., Stupin, A. S. and Lopachev, N. A. (2018). Adaptive Crop Production: Study Guide. St. Petersburg: Lan.

[2] Savary, S., et al. (2019). The Global Burden of Pathogens and Pests on Major Food Crops. Nature Ecology and Evolution, vol. 3, issue 3, pp. 430-438.

[3] Koishibaev M., Mumidzhanov Kh. (2016) Methodological guidelines for monitoring diseases, pests and weeds on crops of grain crops. Food and Agriculture Organization of the United Nations; Ankara, pp 12-28.,

[4] French, E., Kim, B. S. and lyer-Pascuzzi, A. S. (2016). Mechanisms of Quantitative Disease Resistance in Plants. Seminars in Cell and Developmental Biology, vol. 56, pp. 201-208.

[5] Elliott, N. C., Brewer, M. J. and Giles, K. L. (2018). Landscape Context Affects Aphid Parasitism by Lysiphlebus Testaceipes in Wheat Fields. Environmental Entomology, vol. 47 , pp. 803-811.

[6] Bahar B and Yildirim M 2010 Heat and drought resistances criteria in spring bread wheat: Drought resistance parameters Scientific Research and Essays 5(13) 17421745 Retrieved from: http://www.agroatlas.ru. (02.04.2020)

[7] Dubinina O A 2017 Resistance of winter wheat to main stress factors of the environmental and weather conditions Grain economy of Russia vol. 49 pp. 2326.

[8] Pakudin, V. Z. and Lopatina, L. M. (1984). Assessment of Ecological Plasticity and Stability of Crop Varieties. Agricultural biology, vol. 4, pp. 109-113.

[9] Rosielle, A. A. and Hamblin, J. (1981). Theoretical Aspects of Selection for Yield in Stress and Non-Stress Environments. Crop Science, vol. 21, issue 6, pp. 943-946.

[10] Dospekhov, B. A. (1985). Field Experience Methodology (With the Basics of Statistical Processing of Research Results): Textbook For Higher Agricultural Educational Institutions. Moscow: Alliance.

[11] Khangildin, V.V., Litvinenko, N.A. (1986). Parameters of homeostatic assessment of breeding line varieties in tests of spike crops. VASI Scientific and Technical Bulletin, vol. 2, issue 60, pp. 36-41.

[12] Manukyan, I.R., Basieva, M.A., Miroshnikova, E.S., Abiev, V.B. (2019). Assessment of ecological plasticity of winter wheat varieties under conditions of the foothill zone of the Central Caucasus. Agrarian Bulletin of the Urals, vol. 4, pp. 20-26. 
[13] Grabovets A I and Fomenko M A 2015 Climate change and methodology for creating new varieties of wheat and triticale with wide ecological plasticity Achievements of Science and Technology of AIC vol. 29 issue 15, pp. 16-19. 